\title{
Customer Satisfaction Modeling in Hotel Industry: A Case Study of Kish Island in Iran
}

\author{
Pardis Mohajerani (Corresponding author) \\ School of Management, Sharif University of Technology-International Campus, Iran \\ E-mail: pardis.mohajerani@gmail.com
}

Alireza Miremadi

School of Management, Sharif University of Technology-International Campus, Iran

Received: January 15, 2012 Accepted: March 12, 2012 Published: June 1, 2012

doi:10.5539/ijms.v4n3p134 URL: http://dx.doi.org/10.5539/ijms.v4n3p134

\begin{abstract}
Purpose- Hotel Industry is one of the most substantial factors for Tourism Industry. It could provide the necessary substructures for Tourism. Therefore the growth in Tourism industry depends on growth in Hotel industry. Hotel industry had a major growth in recent years in Iran; therefore the purpose of this paper is to explore the customer satisfaction in hotel industry. This paper aims to identify the relation between customer satisfactions as dependent variable with other independent variables such image, customer expectation, service quality, perceived value, locality, and complaining behavior. The second goal of this study was to propose a customer satisfaction model for hotel industry in Kish Island (IRAN). Therefore, the findings of this study will contribute to both hotel management and tourism industry improvement in Iran.

Design/Methodology/approach- A proportional simple random sampling of Iranian visitor to Kish Island were drawn. In this study the researcher had used two different kinds of samples. The first sample was customers of three different hotels of 3 stars, 4 stars, 5 stars which are immeasurable and unlimited. The total number of hotels with the rating of 3 stars, 4 stars, and 5 stars were 22.

Findings- The correlation of image, customer expectation, service quality, perceived value, and customer loyalty are significant enough to show the correlation with customer satisfaction in hotel industry in Iran, furthermore the correlation of complaining behavior and customer was weak and negative, complaint behavior and customer satisfaction is negatively related, which means the lower complaint behavior was, the higher customer satisfaction obtained.

Originality/Value- From a theoretical point of view the results of this study illuminate the relationship between customer satisfaction with variety of factors in Iranian hotel industry. From practical point of view, it explains why certain customer has more trust, experience, loyalty in particular hotels. It is hypothesized and demonstrated empirically that customer satisfaction.
\end{abstract}

Keywords: Customer satisfaction, Service marketing, Customer loyalty, Hotel industry, Tourism industry

\section{Introduction}

Hospitality and tourism Industry has become one of the substantial industries in global industries. Services offering from hospitality industry are necessities because of change in lifestyle. Therefore, to fulfill the demands of growing market, the hospitality market tried to grow and compete with others in market place by meeting consumers needs. Hotel Industry is one of the most substantial factors for Tourism Industry. It could provide the necessary substructures for Tourism. Therefore the growth in Tourism industry depends on growth in Hotel industry. Hotel industry had a major growth in recent years in Iran. However it is not comparable with other countries growth. Two factors lead to growth in Hotel industry. The first one is providing investment opportunities, and the second one refers to increasing customers and the number of travelers. In order to encourage the potential customers to travel, it is necessary to make them satisfied. Customer satisfaction will lead to repurchase intentions and positive word-of-mouth.the significance of this study was its potential contributions to both hotel management and tourism industry improvement in Iran. Services offering from 
hospitality industry are necessities because of change in life style. Therefore, to fulfill the demands of growing market, the hospitality market tried to grow and compete with others in market place by meeting consumers' needs. In order to understand the success rate of hotels, the effect of customer satisfaction and customer loyalty has been a substantial factor. MC Dougall and Lévesque (2000) indicated that service quality, and perceived value are both predictors of customer satisfaction and customer satisfaction has a direct relationship with the repurchase intentions should be analyzed.

\section{Literature Review}

\subsection{Definitions of the Terms}

\subsubsection{Customer Loyalty}

Gremler and Brown (as cited in Kandampully and Suhartunto, 2003) pointed out that service loyalty is considered to be repeat of purchasing behavior from a service provider, showing a positive attitudinal disposition toward the provider, and selecting only this provider when there is a need. According to Kandampully (2003) service loyalty is defined as an organizations commitment to its customers by considering the customer's needs and producing them.

Previous researches indicated that five items would be considered for measuring loyalty included:

(a) Saying positive things about the firm,

(b) Recommending the firm to others,

(c) Encouraging others to do business with the firm,

(d) Considering the firm as the first choice in the future, and

(e) Doing more business with firm in the future (Kandampully and Suhartunto, 2003).

\subsubsection{Customer Loyalty Scale}

The customer loyalty scale had been adapted from several studies conducted by Hsu (2008), Turkyilmaz and Ozkan (2007), Johnson et al. (1998), Kandampully and Suhartunto (2003). At this area, customer Loyalty had three subsections which are:

(a) Positive word-of-mouth,

(b) Switching behavior,

(c) Willingness to pay more.

\subsubsection{Perceived Value}

Previous studies defined value as the result of a product or service usage. HolBrook (as cited in Wu and Liang, 2009) defined consumer value as an interactive relativistic preference experience. And he also emphasized on the transaction between customer and the product from which value results from. Woodall (2003) defined value as the "personal perception of advantage arising out of customer associated with the offering of an organization".

On the other hand, Holbrook (1999) defined eight consumer values in a framework which are efficiency, excellence, play, aesthetics, politics, morality, self-esteem and spirituality.

Hsu pointed out that Parasuramun, et al. (1988) defined perceived value as the consumers overall assessment of the utility of a product, based on the perception of what is received and what is given (Hsu, 2008). Zeithaml (1988) identifies four drivers meaning of value:

(1) Value is low price,

(2) Value is whatever one wants in a product,

(3) Value is the quality that the consumer receives for the price paid, and

(4) Value is what the consumer gets for what they give.

Value is a trade-off between the benefits and sacrifices. Customer value is created when the customer perceives that the benefit of consuming products/ services exceeds the sacrifices (Nasution and Mavondo, 2008).Benefit is quality and sacrifice is identified as price. So, monetary conceptualization is the focus in this definition.

\subsubsection{Perceived Value Scale}

The perceived value scale had been adopted from the study by Nasution and Mavondo (2008). The researchers classified perceived value into three groups of reputation for quality, value for money, and prestige. 


\subsubsection{Complaining Behavior}

A complaint can be defined as a conflict between the customer and the organization (Hsu, 2008). Fornell, et al. (1996) pointed out that the relationship between complaining behaviors and customer satisfaction should be negative and he argued that the results of increased customer satisfaction is a decrease in complaining behavior.

\subsubsection{Complaining Behavior Scale}

The complaining behavior scale had been adopted from one study conducted by Yu and Dean (2000). At this area, complaining behavior had three subsections which are:

(a) Complaining to other customers,

(b) Complaining to other hotels,

(c) Complaining to hotel staffs.

\subsubsection{Service Quality}

In service quality definition, the main focus is on meeting customer's needs and how the service is going to be delivered in accordance with customer expectations (Lewis and Booms, 1983). In Addition, another definition by Klaus (1985) classified service quality into three terms of physical situational and behavioral are mostly focused on service delivery process.

Parasuraman et al. (1985) identified service quality attributes by interviewing customers of four different commercial services. Five main dimensions were found out which were tangibles, reliability, responsiveness, assurance, and empathy.

\subsubsection{Service Quality Scale}

The service quality scale had been adopted from a study by Pollack (2009). At this area, the researcher utilized Hierarchical service quality model (HSQM) which classified service quality into three groups of interaction quality, physical environment quality and outcome Quality.

\subsubsection{Image}

Barich and Kotler ( as cited in Cameran et al. 2009) defined image as the overall impression made on the minds of the public about an organization. Every organization has diversity in images because each customer has different types of experiences and contacts with the company and it will lead to different Images.

\subsubsection{Image Scale}

The image scale had been adopted from two studies conducted by Bosque and Martin (2008), Turkyilmaz and Ozkan (2007). At this area, the researcher classified the image into two categories including cognitive image and affective image.

\subsubsection{Customer Expectation}

Expectation can be described as mutable internal standard which is based on a multitude of factors including needs, objectives, past personal or vicarious experiences with the same establishment Hotel, with similar establishments, and the availability of alternatives (Pizam and Ellis, 1999).

\subsubsection{Customer Expectation Scale}

The customer expectation scale had been adopted from a study from Turkyilmaz and Ozkan (2007). Customer expectation had four parts including:

(a) Expectation for fulfillment of personal need,

(b) Expectation for overall quality,

(c) Expectation for product quality, and

(d) Expectation for service quality.

\subsubsection{Customer Satisfaction}

Hill (1996) pointed out that customer satisfaction will happen when customer's perception met or exceeds his/ her expectations. While Hunt (1977) discussed customer satisfaction as an imaginary assessment of customer about his/ her consumption experience, Oliver (1981) defined it from psychological point of view which is about customer emotions based on his/ her expectations and consumption experience. 


\subsubsection{Customer Satisfaction Scale}

The customer satisfaction scale had been adopted from the study (Juhl et al 2002). At this area, in order to measure customer satisfaction, three main Questions had been asked. The questions covered their satisfaction rate in general, their satisfaction rate in comparison with their expectations, and their satisfaction rate in comparison with their ideal imaginary Hotel.

\subsection{Definition of Customer Satisfaction}

The concept of customer satisfaction is important because it underlies this research. First, customer satisfaction term will be defined generically, then it will be explained Peterson and Wilson (1992) found by their analysis on customer satisfaction that 15,000 academic articles had been published on this topic over two decades.

The shorter oxford English dictionary ("The shorter oxford," 1944, p. 1722) defined satisfaction as "[1] being satisfied, [2] thing that satisfies desire or feeling" it describes satisfy as "[1] to meet whishes of content, [2] to be accepted as adequate [3] to fulfill, [4] comply with, [5] to come up to expectations. Customer has been defined as "a person who buys a product or uses a service."

There are various ways to define customer satisfaction. Oliva et al. (1995) demonstrated customer satisfaction as a function of product performance as opposed to customer expectations.

Oliver (1997) define satisfaction as consumers' fulfillment response, it is an assessment of a product or service feature, or the product or service itself which provided a pleasurable level of consumption- related fulfillment. Skogland (2004) considered levels of under-satisfaction as an overall evaluation of performance based on all prior experiences with a firm.

\subsubsection{Statistical History of Customer Satisfaction: The Evolution of National Satisfaction Index Models}

\subsubsection{SCSB (Swedish Customer Satisfaction Barometer)}

The SCSB model was the first model in customer satisfaction area for products or services which were consumed domestically (Fornell 1992). The sample size was contained 130 companies from 32 of Sweden's largest industries.

This model has two antecedents which are customer expectations based on the performance and perceptions of a customers' performance experience. In this model, Perceived performance and perceived value have equal meaning. Expectation and perceived performance (value) are predicted to have a positive effect on customer satisfaction. Expectation should have a positive effect on perceived performance (value) as well.

\section{Insert Figure 1 here}

There is a theory which is called exit- voice theory from Hirschman (1970). In this theory, Hirschman tried to point out the consequences of customer dissatisfaction which will be appeared by not buying from that firm or complaining to others about that service or product. On the other hand the initial consequences of increased customer satisfaction are increased customer loyalty which will lead to repurchase a particular product or service provider and increase profitability.

Ultimately, there is a relationship between complaining behavior and customer loyalty.

\subsubsection{ACSI (American Customer Satisfaction Index)}

The ACSI model contains six constructs which are customer Expectation, perceived value, perceived quality, customer satisfaction, complaint Behavior, and customer loyalty. It was developed in 1994 by random sampling of 250 of the 200 firms' customers.

\section{Insert Figure 2 here}

This model which was developed based on original SCSB model has a main difference with SCSB which is separating perceived quality concept from perceived value concept. The impact of quality on value was discovered which a positive relationship is.

The NCSB (Norwegian customer satisfaction barometer) model was similar to ACSI but it contains another affective factor on customer satisfaction which is corporate image. Something which is substantial is the kind of organization- related associations in a customer's memory. The other development in NCSB model included commitment construct. This factor has two as peaks, affective and calculative components while affective component is more "hotler" or more emotional and the "colder" aspects of the relationship (Johnson, 2001). So, commitment has a meditating role between satisfaction and loyalty. 


\subsubsection{The European Customer Satisfaction Index}

The ECSI model has contained customer expectations, perceived quality, perceived value, customer loyalty \& customer satisfaction like ACSI. But, the differences between quality and value is standard in ECSI, And loyalty has three main subsets which are likelihood of retention, likelihood of recommending the company or brand, and likelihood of increasing in number of customers. Another substantial difference between ACSI and ECSI is that ECSI does not include complaining behavior as a result of dissatisfaction. The other difference refers to corporate image which has been proved to have a direct effect on customer expectations, satisfaction and loyalty.

Insert Figure 3 here

\subsection{Research Hypothesis}

We have identified the following hypotheses for our research:

\section{H1: There is a relation between image and customer satisfaction.}

An organization's image is a substantial factor that positively or negatively influences marketing activities. Image is considered to have the ability to influence customers' perception of the goods and services offered (Zeithaml and Bitner, 1996).

Mazanec (1995) found image to be positively associated with customer satisfaction and customer preference (a dimension of customer loyalty) in luxury hotels. This shows that a desirable image leads to customer satisfaction and customer preference, while an undesirable image may lead to dissatisfaction. Therefore, it is predicted that image and customer satisfaction have a positive relationship.

\section{H2: There is a relation between customer expectation and customer satisfaction.}

Hayes indicated knowledge of customer expectation and requirements is essential for two reasons- it provides understanding of how the customer defines quality of service and products, and facilities the development of a customer satisfaction indexes (Pizam and Ellisa, 1994). Therefore, it is predicted that customer expectation and customer satisfaction have a positive relationship.

\section{H3: There is a relation between service quality and customer satisfaction.}

Eskildesen et al. (2004) indicated that service quality has significant impact on customer satisfaction. Oliver's (1988) research recommended that service quality and customer satisfaction are related items. Prior period perceptions of service quality cause a revised service quality assessment and so they concluded that satisfaction rapidly becomes part of the revised perception of service quality (Cameran et al. 2009). Therefore, it is predicted that service quality and customer satisfaction has a positive relationship.

\section{$H 4$ : There is a relation between perceived value and customer satisfaction.}

Lea and Bang (2004) examined on line shopping behavior and discovered that customer's perceived value has a positive effect on customer satisfaction. Gallarza and Gil-Sawra (2006) indicated that perceived value is one of the latent variables of customer satisfaction. Sparks et al. (2007) pointed out that with timeshare product; consumer value has a positive and significant relationship with customer satisfaction. Therefore, it is predicted that perceived value and customer satisfaction have a positive relationship.

\section{H5: There is a relation between customer satisfaction and customer loyalty.}

Future purchase intentions of customers are based on their satisfaction (Taylor and Baker, 1994). In 1992, File and Prince indicated that satisfied customers will participate in positive word-of- mouth advertising. Therefore, it is predicted that customer satisfaction and customer loyalty have positive and significant relationship.

\section{H6: There is a relation between customer satisfaction and complaining behavior.}

Fornele et al. (1996) indicated that the immediate result of increased customer satisfaction is a decrease in complaining behavior. Therefore, the variation between complaining behavior and customer satisfaction should be negative. This relationship is totally dependent on organization capabilities of handling the complaints and turning them into customer loyalty. Therefore, it is predicted that customer satisfaction and complaining behavior have negative and significant relationship.

\section{H7: There is a relation between service quality and perceived value.}

Fornell et al. (1996) argued that the inclusion of both perceived quality and perceived value into the ACSI model provides important diagnostic information. As the impact of value increases because of increasing in quality, price becomes a more substantial determinant of satisfaction. Since quality is a component of value, the model also links quality directly to value (Johnson et al. 2001). Therefore, it is predicted that perceived value and 
perceived quality have positive and significant relationship.

\section{H8: There is a relation between expectation and perceived value.}

According to ACSI (American Customer Satisfaction Index) and ECSI (European Customer Satisfaction Index) customer expectation and perceived value have positive relationship with each other. Therefore, it is predicted that perceived value and customer expectations have positive and significant relationship in this research too.

\section{Methodology}

After defining the research, the researcher needs to execute the research methodology to pursue the topic. In this study the Researcher selected the quantitative research methodology to pursue her research. It provides statistics through the use of large scale survey research, using methods such a questionnaires or structured interview.

\section{Research Design}

George J. Mouly has classified research methods into three basic types: Survey, historical and experimental methods. In this research the survey method had been utilized. It focused on present situation and tried to find about the object under investigation. This method has been further classified into four categories: (a) Descriptive (b) Analytical (c) School survey and (d) Genetic.

The research design utilized in this study was a descriptive survey design. Fraenkel and Wallen (2003) argued that a descriptive survey involves asking the same set of questions from a large number of individuals. The main advantage of this type of research is to provide a lot of information from a large sample of individuals. Fraenkel and Wallen listed three major characteristics that most surveys possess:

- Information is collected from a group of people in order to describe some aspects or characteristics of the population of which that group is a part.

- $\quad$ The main way in which the information is being collected is through asking questions; the answers to these questions by the members of the group constitute the data of study.

- Information is collected from a sample rather than from every member of the population.

\subsection{The Research Approach}

\subsubsection{The Sample}

There are numerous valid reasons for selecting Kish Island for a study on tourism. As an island, Kish has many tourism resources which stimulate travel within its borders. The diverse climate, scenery, wildlife, man-made attractions such as theme and amusement parks attract numerous visitors (Timmons, 1989). Many events occur within the areas of sporting culture, and festivals which attract tourists to Kish island every year (Timrnons, 1989).Winter (March, 2010) had been chosen as a time period since this is the best season for traveling to south of the country (Kish Island), Therefore a large number of travelers come to Kish Island because of its low temperature in this season.

\subsubsection{Sample Size}

In this research the sample was customers of three different hotels of 3 star, 4 star, 5 star which is immeasurable and unlimited. The researcher distributed one questionnaire for each hotel manager in Kish Island to obtain its response.

There are three traditional approaches to determining sample size. The size of the sample may be determined through the good judgment of the researcher (Green, TulI \& Albaum, 1988). The use of the budget and the cost of the research may be another determinant of the sample size (Green et al., 1988). Finally, the fact that the researcher has attracted all potential participants may determine sample size (Green et al., 1988). In this research, all of these factors were considered when determining sample size.

In this research, proportional simple random sampling had been utilized. According to following formula with confidence interval of $95 \%$ and the measured p-value of $75 \%$, the minimum total sample size had become 285 . P-value had been measured by considering the percentage of the customers whose satisfaction rate proved to be above average.

$$
n=\frac{z^{2} p q}{e^{2}}
$$




$$
n=\frac{(1.96)^{2}(0.75)(0.25)}{(0.05)^{2}} \Rightarrow n=285
$$

In order to collect the data, International Kish Airport had been chosen because we could distribute the questionnaire among a large number of customers of the domestic flights who were leaving Kish Island. Three days and four hours a day had been selected randomly. As a result every 5th traveler who entered the departure hall was selected to participate in the study.

\subsubsection{Instrument}

A comprehensive review of literature assisted the researcher in creating the instrument by locating an existing customer satisfaction survey that was utilized in similar studies.

The instrument used in this study was designed in a form of the customer satisfaction questionnaire. The researcher decided to use the questions from existing surveys where validity was already determined. However, due to slight adaptation, the researcher further reviewed for validity using a panel of experts to review the questions and content.

The questions in the survey were designed to gather information on the customers' opinion about the services that they received from hotels. The customer satisfaction questionnaire contains 40 statements in total. The customer satisfaction questionnaire is represented by the 7 following areas: perceived quality, perceived value, customer expectation, customer satisfaction, image, customer loyalty, complaining behavior. Each item had its own sub-items, and the number of related questions is demonstrated below.

Customer loyalty encompasses three main subsections including positive word-of-mouth (three questions), willingness to pay more (one question), and switching behavior (two questions). Perceived quality (thirteen questions), perceived value (four questions), customer satisfaction (three questions), complaining behavior (three questions), image (eight questions), and customer expectation (three questions).

According to literature review, three main indexes of perceived value, perceived quality, image which had been used in our research had common sub-items. In order to solve this problem clustering method had been utilized in SPSS software to classify each sub index under its more related index.

\subsubsection{Pilot Study}

The researcher carried out the pilot testing study to see whether the questionnaires can obtain the results which the researcher required for meeting his objectives and hypotheses. Since the researcher has found the relevant data, it wasn't necessary to pilot the questionnaires again.

Internal consistency or reliability of the instrument was calculated by finding Cronbach alpha coefficient. Cronbach's alpha is an index of reliability associated with calculating the reliability of items that are not scored right versus wrong (Fraenkel \& Wallen, 2003). Alpha coefficient ranges in value from 0 to 1 and may be used to describe the reliability of factors obtained from multi-point formatted questionnaires or scales (i.e., rating scale: $1=$ very dissatisfied, $5=$ very satisfied) (Fraenkel $\&$ Wallen, 2003). The higher the score, the more reliable the scale is. Nunnaly (1978) has indicated 0.7 to be an acceptable reliability coefficient. The alpha for this instrument was computed at 0.914 .

When Cronbach's was from 0.35 to 0.70 , the reliability of the instrument was medium. When it was above 0.70 , the reliability of the instrument was high. If it was below 0.35 , it shows low reliability and the instrument should not be used. According to the researcher's results of completed questionnaires and using. 0/7 Cronbache's alpha value as the cut-off, the results of the reliability test show that all variables are reliable.

\section{Insert Table 1 here}

Content validity: The theoretic foundation for this analysis had been adopted from the study (Juhl, et al. 2002).At this area, in order to measure customer satisfaction, three main questions had been asked from customers which showed their satisfaction rate in general, their satisfaction rate in comparison with their expectations, and their satisfaction rate in comparison with their ideal hotel. The researcher selected related variables and rubrics to develop the instrument of this study. Before and after distributing survey questionnaires, the researcher invited two marketing professor of Sharif university of technology (international campus) to review the questionnaire to help in improving the content validity of the questionnaire in practical and executive way.

Construct validity: Validity is the property by which a questionnaire measure what it is supposed to measure, for example, if researcher wants to measure customer satisfaction towards hotel industry in Kish island in terms 
of variety of indexes then that is what the critical questions in the questionnaire should measure. One of the difficulties arising in attitude measurements is that it is perhaps impossible to measure attitude directly, therefore the researcher found the construct validity as the best tool to overcome this problem. In order to apply construct validity, the researcher postulates the nature and extent of association between attitude (customer satisfaction) and other specified independent variables.

It is worth noting that the construct validity is based on theoretical consideration, therefore the researcher used dependent variables (customer satisfaction) with other independent variables, and thus the existence of a high degree of correlation in this study is supporting evidence and can be regarded as a test of validity.

\subsubsection{Procedure}

Sharif University of technology (international campus) permitted to conduct the research in Kish Island. After the researcher defines the research questions and related literature, a survey questionnaire was modified and created. During the designing of the questionnaire, the researcher studied and compared various Persian and English questionnaires and the following steps were taken to prepare the English version questionnaire:

1) The researcher first asked an English instructor to translate the English version questionnaire into Persian.

2) In order to make sure that the Persian translation did not deviate from the original English version, it was translated back into English by English. The researcher was invited to read both versions of the English questionnaires to make sure that the texts were translated in correct way.

The researcher did several methods to conduct pilot testing:

For this study, two professors in Sharif University of technology examined the wording and the content of the questions. After that, the questionnaire was finalized.

The researcher used several methods to conduct pilot testing:

The researcher requested the professional executives in the field of Marketing and tourism industry and a professor to review the questionnaires to check if there is any ambiguity the researcher hasn't noticed.

A pilot study was conducted among customers of Kish Island hotels in IRAN in February, 2010. A total of 50 questionnaires were sent out to customers, and 40 valid questionnaires were returned. The purpose of the pilot study was to test the reliability, validity, and objectivity of the survey questionnaire. After data was collected; the researcher analyzed it to test the reliability and validity. The results were used to modify the initial survey questionnaire if necessary.

After the survey questionnaire had been modified and assessed for reliability and validity, the researcher officially conducted the survey. There were 22 different 3 stars, 4 star, 5 star hotels, and 300 questionnaires were distributed among customers. In order to gather the data, International Kish Airport had been an excellent choice because the researcher could distribute the questionnaire among a large number of customers of the domestic flights who were leaving Kish Island. Three days and four hours a day had been chosen randomly. As a result every 5th traveler who entered the departure hall was selected to participate in the study. After the researcher collects the completed surveys, 15 questionnaires were proved to be invalid, total numbers of 285 questionnaires were valid.

\section{Results}

\subsection{Coloration}

H1: There is a relation between image and customer satisfaction.

The correlation of image and customer satisfaction was $0.823, \mathrm{p}<.01$. It was significant enough to show the correlation of the two variables. Because the correlation was strong and positive, image and customer satisfaction is positively related, which means the better the image, the higher the customer satisfaction (Table II).

H2: There is a relation between customer expectation and customer satisfaction.

The correlation of customer expectation and customer satisfaction was $0.504, \mathrm{P}<.01$. It was significant enough to show the correlation of the two variables. Because the correlation was medium and positive, customer expectation and customer satisfaction is positively related, which means the better the customer expectation, the higher the customer satisfaction (Table 2).

H3: There is a relation between service quality and customer satisfaction.

The correlation of service quality and customer satisfaction was $0.709, \mathrm{p}<.01$. It was significant enough to show 
the correlation of the two variables. Because the correlation was strong and positive, service quality and customer satisfaction is positively related, which means the better service quality was, the higher customer satisfaction became (Table 2).

H4: There is a relation between perceived value and customer satisfaction.

The correlation of perceived value and customer satisfaction was $0.826, p<.01$. It was significant enough to show the correlation of the two variables. Because the correlation was strong and positive, perceived value and customer satisfaction is positively related, which means the better perceived value was, the higher customer satisfaction became (Table 2).

H5: There is a relation between customer satisfaction and customer loyalty.

The correlation of customer loyalty and customer satisfaction was $0.697, \mathrm{p}<.01$. It was significant enough to show the correlation of the two variables. Because the correlation was strong and positive, customer loyalty and customer satisfaction is positively related, which means the better customer satisfaction was, the higher customer loyalty became (Table 2).

H6: There is a relation between customer satisfaction and complaining behavior.

The correlation of complaining behavior and customer satisfaction was $-0.130, \mathrm{p}<.05$. It was significant enough to show the correlation of the two variables. Because the correlation was weak and negative, complaint behavior and customer satisfaction is negatively related, which means the lower complaint behavior was, the higher customer satisfaction became (Table 2).

H7: There is a relation between service quality and perceived value.

The correlation of service quality and perceived value was $0.720, p<.01$. It was significant enough to show the correlation of the two variables. Because the correlation was strong and positive, service quality and perceived value is positively related, which means the better service quality was, the higher perceived value became (Table 2).

H8: There is a relation between customer expectation and perceived value.

The correlation of customer expectation and perceived value was $0.443, \mathrm{p}<.01$. It was significant enough to show the correlation of the two variables. Because the correlation was positive, customer expectation and perceived value is positively related, which means the better customer expectation was, the higher perceived value became (Table 2).

Insert Table 2 here

\title{
4.2 Normality Test
}

According to Figures 7, 8 the normality of the population has been approved. A histogram of the residuals to be compared a normal probability curve. If the actual distribution of the residuals (the histogram) was bell-shaped and similar to the normal distribution, this population would be normal.

\section{Insert Figure 4 and 5 here}

\subsection{Linearity and Equality of Variances Assessment}

According to Figure 9 the researcher plots two of the following: standardized predicted values, and standardized residuals. By plotting the standardized residuals against the standardized predicted values the researcher wanted to check for linearity and equality of variances. The following plot indicates that there exists equality of variances but no linearity had been observed.

\section{Insert Figure 6 here}

\subsection{Researcher Considered Forward Regression Method to Determine the Basic Predictor Factors in the Model}

\author{
Insert Figure 7 and Table 3 here
}

According the regression results (Table 3 ) every four factors (customer expectation, perceived quality, perceived value, image) reached the $t$ value of significance $\mathrm{p}<.01$ (customer expectation $\mathrm{t}=3.909$, perceived quality $\mathrm{t}=2.089$, perceived value $\mathrm{t}=7.705$, image $\mathrm{t}=7.216$ ). Customer expectation, perceived quality, perceived value, image were close to the variable of 76.7\% (Adjusted R Square.767) in relation to Customer Satisfaction Indicates that 76.7\% of the variance can be predicted from the independent variables. R Square of $77 \%$ indicates that achieved regression formula is acceptable for $77 \%$ of data. 
The next important part of the output is the Tolerance and VIF values in the Coefficients table for the existence of multicollinearity. A tolerance of less than 0.20 or 0.10 and/or a VIF of 5 or 10 and above indicates a multicolinearity problem (O'Brien, 2007). The researcher does not need to worry about multicolinearity. Here are the values to check for multicollinearity.

Insert Table 4 here

The ANOVA table $\mathrm{V}$ shows that $\mathrm{F}-234.294$ and it is significant. This indicates that the combination of the predictors significantly predict customer satisfaction.

\section{Insert Table 5 here}

Researcher is considering General Linear Model (MANOVA) that had been used to determine about customer satisfaction consequences in the model. The GLM Multivariate procedure provides an analysis for "effects" on a linear combination of several dependent variables of one or more fixed factors or independent variables and covariates.

\section{Insert Figure 8 and Table 6 here}

According to results of MANOVA (Table 6), customer loyalty and complaining behavior are both significantly effective in this model (customer loyalty $\mathrm{t}=16.374$, complaining behavior $\mathrm{t}=-2.211$ ). In addition, the positive relationship between customer loyalty and negative relationship between complaining behavior and customer satisfaction were clear.

In most conditions when assumptions are met, Wilks Lambda (Table 7) provides a good and commonly used multivariate $\mathrm{F}$ (in this case $\mathrm{F}=1.337, \mathrm{df}=2, \mathrm{Sig}=.000$ ). This significant $\mathrm{F}$ indicates that there are significant differences between the customer loyalty and complaining behavior on a linear combination of the two dependent.

\section{Insert Table 7 here}

According to the results, Table 8 showed that the effect size of customer loyalty is significantly large which is about 0.486 and complaining behavior has small effective size in this model which is about 0.017 .

Insert Table 8 here

\subsection{Proposed Model}

$$
\text { Insert Figure } 9 \text { here }
$$

\section{Discussion, Implication and Conclusion}

Hospitality and tourism Industry has become one of the substantial industries in global industries. Services offered by hospitality industry are necessary because of change in lifestyle. Therefore, to fulfill the demands of the growing market, the hospitality market tried to grow and compete with others in the market place by meeting consumers needs.

In this research, numerous objectives had been pursued. The first purpose of this study was to identify the drivers of customer satisfaction and their relationship with customer satisfaction. The second goal of this study was to propose a customer satisfaction model for hotel industry in Kish Island (IRAN). It has been concluded that perceived value, perceived quality, image, and customer expectation have positive effects on customer satisfaction. In addition customer satisfaction has a positive impact on customer loyalty and negative impact on complaining behaviour; according to the results extracted from the research it was proved that customer satisfaction can be predicted by image, customer expectation, perceived value, and perceived quality. Moreover, customer loyalty and complaining behavior are the different results of customer satisfaction. The findings of this study will contribute to both hotel management and tourism industry improvement in Iran. Services offered by hospitality industry are necessary because they could change the lifestyle. The findings are limited to tourist visitors in Kish Island in Iran; the generalization of results could be extended by broadening the list of all hotel industry in Iran and measure the customer satisfaction with respective factors and attributes. This allows construct the practical and executive model of customer satisfaction in Iran.

\section{References}

Barich, H., \& Kotler, P. (1991). A Framework for Marketing Image Management. Sloan Management Review, 32(2), 94-104.

Bosque, I., \& Martin, H. (2008). Tourist Satisfaction A Cognitive-Affective Model. Annals of Tourism Research, 35, 551-573. http://dx.doi.org/10.1016/j.annals.2008.02.006 
Cameran, M., Moizer, P., \& Pettinicchio, A. (2009). Customer Satisfaction, Corporate Image, and Service Quality in Professional Services. The Service Industries Journal, 30(3), 421-435. http://dx.doi.org/10.1080/02642060802236111

Dean, A., \& Yu, Y. (2001). The Contribution of Emotional Satisfaction to Consumer Loyalty. International Journal of Service Industry Management, 12(3), 234-250. http://dx.doi.org/10.1108/09564230110393239

Eskildsen, J., Kristensen, K., Juhl, H.T., \& Ostergaard, P. (2004). The Drivers of Customer Satisfaction and Loyalty. The Case of Denmark 2000-2002. Total Quality Management, 15(5-6), 859-868. http://dx.doi.org/10.1080/14783360410001680297

File, K. M., \& Prince, R. A. (1992). Positive Word Of Mouth: Customer Satisfaction and Buyer Behavior. International Journal of Bank Marketing, 10(1), 25-29. http://dx.doi.org/10.1108/02652329210007867

Fornell, C. (1992). A national customer satisfaction barometer: The Swedish experience. Journal of Marketing, 56(1), 1-21. http://dx.doi.org/10.2307/1252129

Fornell, C., Johnson, M. D., Anderson, E. Cha W. J., \& Bryant, B. E. (1996). The American Customer Satisfaction Index: Nature, purpose, and findings. Journal of Marketing, 607-618.

Fraenkel, J., \& Wallen, N. (2003). How to design and evaluate research in Education. NY: McGraw-Hill.

Gallarza, M. G., \& Gil-Saura, I. G. (2006). Value dimensions, perceived value, satisfaction and loyalty: an investigation of university students' travel behavior. Tourism Management, 27, 437-452. http://dx.doi.org/10.1016/j.tourman.2004.12.002

Green, P. E., Tull, D., \& Albaum, S. (1988). Research for Marketing Decisions (5th ed.). New Jersey: Prentice Hall.

Hans, J., Juhl, M., Kristensen, K., \& Østergaard, P. (2002). Customer satisfaction in European food retailing, Journal of Retailing and Consumer Services, 9, 327-334. http://dx.doi.org/10.1016/S0969-6989(02)00014-0

Hill, N. (1996). Handbook of Customer Satisfaction. Aldershot. Gower Publishing Limited.

Holbrook, M. B. (1999). Introduction to consumer value: A Framework for Analysis and Research. Routledge, London, New York, 1-28. http://dx.doi.org/10.4324/9780203010679.ch0

Hsu, S. H. (2008). Developing an index for online customer satisfaction: Adaptation of American Customer Satisfaction Index. Expert Systems with Applications, 34, 3033-3042. http://dx.doi.org/10.1016/j.eswa.2007.06.036

Hunt, D. W., \& Hanks, J. (1995). ED Extremists. Emergency Medical Services, 33-83.

Johnson, M. D., Gustafsson, A., Andreassen, T. W., Lervik, L., \& Cha, J. (2001). The evolution and future of national customer satisfaction index models. Journal of Economic Psychology, 22(2), 217-245. http://dx.doi.org/10.1016/S0167-4870(01)00030-7

Kandampully, J., \& Suhartanto, D. (2003). The Role of Customer Satisfaction and Image in Gaining Customer Loyalty in the Hotel Industry. Journal of Hospitality \& Leisure Marketing, 10, 54-63. http://dx.doi.org/10.1300/J150v10n01_02

Klaus, P. (1985). Quality epiphenomenon: the conceptual understanding of quality in face-to face service encounters, 17-33.

Lee, C. S., \& Bang, S. B. (2004). The effects of shopping value on online purchasing intention: focus on product attribute importance as intervening variables. Korean Marketing Research, 19(2), 41-69.

Lewis, R. C., \& Booms, B. (1983). The Marketing Aspects of Service Quality. Chicago, American Marketing Association.

Mazanec, J. A. (1995). Positioning Analysis with Self-Organizing Maps: An Exploratory Study on Luxury Hotels. Cornell H.R.A. Quarterly, 12, 80-92.

McDougall, G. H. G., \& Leveque, T. (2000). Customer satisfaction with services: putting perceived value into the equation. Journal of Services Marketing, 14(5), 392-410. http://dx.doi.org/10.1108/08876040010340937

Mouly, J. G. (1970). The Science of Educational Research Methods. University of London Press Ltd.

Nasution, H. N., \& Mavondo, F. T. (2008). Customer value in the hotel industry: What managers believe they deliver and what customer experience. International Journal of Hospitality Management, 27, 204-213. http://dx.doi.org/10.1016/j.ijhm.2007.02.003 
Nunnally, J. C., \& Benstein, H. (1994). Psychometric Theory. NY: McGraw-Hill.

O'BRIEN, R. M. (2007). A Caution Regarding Rules of Thumb for Variance Inflation Factors. Quality \& Quantity, 41, 673-690. http://dx.doi.org/10.1007/s11135-006-9018-6

Oliva, T. A., Oliver, R. L., \& Bearden, W. O. (1995). The Relationships among consumer satisfaction involvement, and product performance: A catastrophe theory application. Behavioral Science, 40(2), 104-132. http://dx.doi.org/10.1002/bs.3830400203

Oliver, R. L. (1981). Measurement and Evaluation of Satisfaction Processes in Retail Settings. Journal of Retailing, 57(3), 25-48.

Oliver, R. L. (1997). Satisfaction A Behavioral Perspective of the Consumer. New York: McGraw-Hill.

Parasuraman, A., Zeithaml, V. A., \& Berry, L. L. (1985). A conceptual model of service quality and its implications for future research. Journal of Marketing, 49(4), 41-50. http://dx.doi.org/10.2307/1251430

Peterson, R. A., \& Wilson, W. R. (1992). Measuring Customer Satisfaction: Fact and Artifact. Journal of the Academy of Marketing Science, 20, 61-71. http://dx.doi.org/10.1007/BF02723476

Pizam, A., \& Ellis, T. (1999). Customer Satisfaction and Its Measurement in Hospitality Enterprises. International Journal of Contemporary Hospitality Management, 11(7), 326-339. http://dx.doi.org/10.1108/09596119910293231

Pollack, B. L. (2009). Linking the Hierarchical Service Quality Model to Customer Satisfaction and Loyalty. Journal of Services Marketing, 23(1), 42-50. http://dx.doi.org/10.1108/08876040910933084

Skogland, I., \& Siguaw, J. A. (2004). Are Your Satisfied Customers Loyalty. Cornell Hotel and Restaurant Administration Quarterly, 45(3), 221-234. http://dx.doi.org/10.1177/0010880404265231

Taylor, S. A., \& Baker, T. L. (1994). An Assessment of the Relationship between Service Quality and Customer Satisfaction In The Formation Of Consumers' Purchase Intentions. Journal of Retailing, 70(2), 163-178. http://dx.doi.org/10.1016/0022-4359(94)90013-2

Timmons, V. (1989). Tourism and Travel (3rd ed.). Vancouver: Timmons and Associates.

Trkyılmaz, A., \& Ozkan, C. (2007). Development of a customer satisfaction index model an application to the Turkish mobile phone sector. Industrial Management \& Data Systems, 107(5), 672-687. http://dx.doi.org/10.1108/02635570710750426

Woodall, T. (2003). Conceptualizing 'value for the customer': an attribution, structural and dispositional analysis. Academy of Marketing Science Review, 12. [Online] Available: http://www.amsreview.org/articles/woodall12-2003.pdf.

Zeithamland, V. A., \& Bitner, M. J. (1996). Services Marketing (International Ed). NY: McGraw-Hill.

Table 1. Reliability analysis

\begin{tabular}{|c|c|c|}
\hline Cronbach's Alpha & $\begin{array}{c}\text { Cronbach's Alpha } \\
\text { Based on } \\
\text { Standardized Items }\end{array}$ & N of Items \\
\hline .912 & .914 & 40 \\
\hline
\end{tabular}


Table 2. Correlation

\begin{tabular}{|c|c|c|c|c|c|c|c|c|}
\hline & & quality & $\begin{array}{c}\text { Complaining } \\
\text { behavior }\end{array}$ & $\begin{array}{c}\text { Customer } \\
\text { satisfaction }\end{array}$ & image & loyalty & value & $\begin{array}{c}\text { Customer } \\
\text { expectation }\end{array}$ \\
\hline \multirow[t]{3}{*}{ quality } & $\begin{array}{c}\text { Pearson } \\
\text { Correlation }\end{array}$ & 1 & -.111 & $.709^{* *}$ & $.735^{* *}$ & $.574^{* *}$ & $.720^{* *}$ & $.400^{* *}$ \\
\hline & Sig. (2-tailed) & & .061 & .000 & .000 & .000 & .000 & .000 \\
\hline & $\mathrm{N}$ & 286 & 285 & 285 & 285 & 285 & 285 & 285 \\
\hline \multirow[t]{3}{*}{$\begin{array}{l}\text { Complaining } \\
\text { behavior }\end{array}$} & $\begin{array}{c}\text { Pearson } \\
\text { Correlation } \\
\end{array}$ & -.111 & 1 & $-.130^{*}$ & $-.129^{*}$ & $-.208^{* *}$ & -.105 & -.009 \\
\hline & Sig. (2-tailed) & .061 & & .028 & .030 & .000 & .076 & .882 \\
\hline & $\mathrm{N}$ & 285 & 285 & 285 & 285 & 285 & 285 & 285 \\
\hline \multirow[t]{3}{*}{ image } & $\begin{array}{c}\text { Pearson } \\
\text { Correlation }\end{array}$ & $.735^{* *}$ & $-.129^{*}$ & $.823^{* *}$ & 1 & $.648^{* *}$ & $.806^{* *}$ & $.433^{* *}$ \\
\hline & Sig. (2-tailed) & .000 & .030 & .000 & & .000 & .000 & .000 \\
\hline & $\mathrm{N}$ & 285 & 285 & 285 & 285 & 285 & 285 & 285 \\
\hline \multirow[t]{3}{*}{ loyalty } & $\begin{array}{c}\text { Pearson } \\
\text { Correlation }\end{array}$ & $.574^{* *}$ & $-.208^{* *}$ & $.697^{* *}$ & $.648^{* *}$ & 1 & $.712^{* *}$ & $.298^{* *}$ \\
\hline & Sig. (2-tailed) & .000 & .000 & .000 & .000 & & .000 & .000 \\
\hline & $\mathrm{N}$ & 285 & 285 & 285 & 285 & 285 & 285 & 285 \\
\hline \multirow[t]{3}{*}{ value } & $\begin{array}{c}\text { Pearson } \\
\text { Correlation }\end{array}$ & $.720^{* *}$ & -.105 & $.826^{* *}$ & $.806^{* *}$ & $.712^{* *}$ & 1 & $.443^{* *}$ \\
\hline & Sig. (2-tailed) & .000 & .076 & .000 & .000 & .000 & & .000 \\
\hline & $\mathrm{N}$ & 285 & 285 & 285 & 285 & 285 & 285 & 285 \\
\hline \multirow[t]{3}{*}{$\begin{array}{c}\text { Customer } \\
\text { expectation }\end{array}$} & $\begin{array}{c}\text { Pearson } \\
\text { Correlation }\end{array}$ & $.400^{* *}$ & -.009 & $.504^{* *}$ & $.433^{* *}$ & $.298^{* *}$ & $.443^{* *}$ & 1 \\
\hline & Sig. (2-tailed) & .000 & .882 & .000 & .000 & .000 & .000 & \\
\hline & $\mathrm{N}$ & 285 & 285 & 285 & 285 & 285 & 285 & 285 \\
\hline \multicolumn{9}{|c|}{$\begin{array}{l}* * \text {. Correlation is significant at the } 0.01 \\
\text { level (2-tailed). }\end{array}$} \\
\hline \multicolumn{3}{|c|}{$\begin{array}{l}* \text {. Correlation is significant at the } 0.05 \\
\text { level (2-tailed). }\end{array}$} & & & & & & \\
\hline
\end{tabular}

Table 3. Model summary

\begin{tabular}{|c|c|c|c|c|}
\hline Model & $\mathbf{R}$ & R Square & Adjusted R Square & Std. Error of the Estimate \\
\hline 1 & $.826^{\mathrm{a}}$ & .682 & .681 & .58055 \\
\hline 2 & $.868^{\mathrm{b}}$ & .753 & .751 & .51312 \\
\hline 3 & $.875^{\mathrm{c}}$ & .766 & .764 & .49950 \\
\hline 4 & $.877^{\mathrm{d}}$ & .770 & .767 & .49653 \\
\hline \\
a. Predictors: (Constant), value \\
\hline b. Predictors: (Constant), value, image \\
c. Predictors: (Constant), value, image, customer expectation \\
\hline
\end{tabular}


Table 4. Coefficients

\begin{tabular}{|c|c|c|c|c|c|c|c|c|}
\hline \multirow{2}{*}{\multicolumn{2}{|c|}{ Model }} & \multicolumn{2}{|c|}{$\begin{array}{l}\text { Unstandardized } \\
\text { Coefficients }\end{array}$} & \multirow{2}{*}{$\begin{array}{c}\begin{array}{c}\text { Standardized } \\
\text { Coefficients }\end{array} \\
\text { Beta }\end{array}$} & \multirow[t]{2}{*}{$\mathbf{t}$} & \multirow[t]{2}{*}{ Sig. } & \multirow{2}{*}{$\begin{array}{c}\text { co linearity } \\
\text { tolerance }\end{array}$} & \multirow[b]{2}{*}{ VIF } \\
\hline & & $B$ & Std. Error & & & & & \\
\hline \multirow[t]{2}{*}{1} & (Constant) & .229 & .125 & & 1.831 & .068 & & \\
\hline & value & .950 & .039 & .826 & 24.645 & .000 & 1.000 & 1.000 \\
\hline \multirow[t]{3}{*}{2} & (Constant) & -.362 & .129 & & -2.811 & .005 & & \\
\hline & value & .535 & .058 & .465 & 9.304 & .000 & .351 & 2.849 \\
\hline & image & .584 & .065 & .448 & 8.959 & .000 & .351 & 2.849 \\
\hline \multirow[t]{4}{*}{3} & (Constant) & -.664 & .146 & & -4.558 & .000 & & \\
\hline & value & .494 & .057 & .430 & 8.688 & .000 & .340 & 2.940 \\
\hline & image & .547 & .064 & .419 & 8.526 & .000 & .344 & 2.908 \\
\hline & $\begin{array}{c}\text { Customer } \\
\text { expectation }\end{array}$ & .156 & .038 & .132 & 4.074 & .000 & .787 & 1.270 \\
\hline \multirow[t]{5}{*}{4} & (Constant) & -.850 & .170 & & -5.002 & .000 & & \\
\hline & value & .457 & .059 & .397 & 7.705 & .000 & .309 & 3.234 \\
\hline & image & .494 & .068 & .379 & 7.216 & .000 & .298 & 3.359 \\
\hline & $\begin{array}{l}\text { Customer } \\
\text { expectation }\end{array}$ & .149 & .038 & .127 & 3.909 & .000 & .782 & 1.279 \\
\hline & quality & .140 & .067 & .094 & 2.089 & .038 & .410 & 2.439 \\
\hline \multicolumn{4}{|c|}{$\begin{array}{l}\text { a. Dependent Variable: customer } \\
\text { satisfaction }\end{array}$} & & & & & \\
\hline
\end{tabular}

Table 5. ANOVA

\begin{tabular}{|c|c|c|c|c|c|c|}
\hline \multicolumn{2}{|c|}{ Model } & \multirow{2}{*}{$\begin{array}{c}\text { Sum of Squares } \\
204.705\end{array}$} & \multirow{2}{*}{$\begin{array}{c}\mathbf{d f} \\
1\end{array}$} & \multirow{2}{*}{$\begin{array}{c}\text { Mean Square } \\
204.705\end{array}$} & \multirow{2}{*}{$\begin{array}{c}\mathbf{F} \\
607.365\end{array}$} & \multirow{2}{*}{$\begin{array}{l}\text { Sig. } \\
.000^{\mathrm{a}}\end{array}$} \\
\hline 1 & Regression & & & & & \\
\hline & Residual & 95.382 & 283 & .337 & & \\
\hline & Total & 300.087 & 284 & & & \\
\hline \multirow[t]{3}{*}{2} & Regression & 225.838 & 2 & 112.919 & 428.868 & $.000^{\mathrm{b}}$ \\
\hline & Residual & 74.249 & 282 & .263 & & \\
\hline & Total & 300.087 & 284 & & & \\
\hline \multirow[t]{3}{*}{3} & Regression & 229.979 & 3 & 76.660 & 307.259 & $.000^{\mathrm{c}}$ \\
\hline & Residual & 70.108 & 281 & .249 & & \\
\hline & Total & 300.087 & 284 & & & \\
\hline \multirow[t]{3}{*}{4} & Regression & 231.055 & 4 & 57.764 & 234.294 & $.000^{\mathrm{d}}$ \\
\hline & Residual & 69.032 & 280 & .247 & & \\
\hline & Total & 300.087 & 284 & & & \\
\hline \multicolumn{4}{|c|}{ a. Predictors: (Constant), value } & & & \\
\hline
\end{tabular}

Table 6. Parameter estimates

\begin{tabular}{|c|c|c|c|c|c|c|c|c|c|c|}
\hline \multirow[t]{2}{*}{$\begin{array}{l}\text { Dependent } \\
\text { Variable }\end{array}$} & \multirow[t]{2}{*}{ Parameter } & \multirow[t]{2}{*}{ B } & \multirow[t]{2}{*}{$\begin{array}{l}\text { Std. } \\
\text { Error }\end{array}$} & \multirow[t]{2}{*}{$\mathbf{t}$} & \multirow[t]{2}{*}{ Sig. } & \multicolumn{2}{|c|}{$\begin{array}{c}95 \% \\
\text { Confidence } \\
\text { Interval } \\
\end{array}$} & \multirow[t]{2}{*}{$\begin{array}{c}\text { Partial } \\
\text { Eta } \\
\text { Squared }\end{array}$} & \multirow[t]{2}{*}{$\begin{array}{l}\text { Noncent. } \\
\text { Parameter }\end{array}$} & \multirow[t]{2}{*}{$\begin{array}{l}\text { Observed } \\
\text { Power }^{\mathrm{a}}\end{array}$} \\
\hline & & & & & & $\begin{array}{l}\text { Lower } \\
\text { Bound }\end{array}$ & $\begin{array}{l}\text { Upper } \\
\text { Bound }\end{array}$ & & & \\
\hline \multirow[t]{2}{*}{ loyalty } & Intercept & 1.190 & .100 & 11.927 & .000 & .993 & 1.386 & .335 & 11.927 & 1.000 \\
\hline & $\begin{array}{c}\text { Customer } \\
\text { satisfaction }\end{array}$ & .486 & .030 & 16.374 & .000 & .428 & .545 & .486 & 16.374 & 1.000 \\
\hline \multirow{2}{*}{$\begin{array}{l}\text { Complaining } \\
\text { behavior }\end{array}$} & Intercept & 3.614 & .138 & 26.202 & .000 & 3.343 & 3.886 & .708 & 26.202 & 1.000 \\
\hline & $\begin{array}{c}\text { Customer } \\
\text { satisfaction }\end{array}$ & -.091 & .041 & -2.211 & .028 & -.172 & -.010 & .017 & 2.211 & .596 \\
\hline \multicolumn{2}{|c|}{$\begin{array}{l}\text { a. Computed using alpha } \\
=.05\end{array}$} & & & & & & & & & \\
\hline
\end{tabular}


Table 7. Multivariate test

\begin{tabular}{|c|c|c|c|c|c|c|c|c|c|}
\hline \multicolumn{2}{|c|}{ Effect } & Value & F & $\begin{array}{c}\text { Hypothesis } \\
\text { df }\end{array}$ & Error df & Sig. & $\begin{array}{c}\text { Partial } \\
\text { Eta } \\
\text { Squared }\end{array}$ & $\begin{array}{c}\text { Noncent. } \\
\text { Parameter }\end{array}$ & $\begin{array}{c}\text { Observed } \\
\text { Power }\end{array}$ \\
\hline Intercept & $\begin{array}{c}\text { Wilks' } \\
\text { Lambda }\end{array}$ & .228 & $4.775 \mathrm{E}^{\mathrm{a}}$ & 2.000 & 282.000 & .000 & .772 & 954.932 & 1.000 \\
\hline $\begin{array}{c}\text { Customer } \\
\text { Satisfaction }\end{array} \begin{array}{c}\text { Wilks' } \\
\text { Lambda }\end{array}$ & .513 & $1.337 \mathrm{E2}^{\mathrm{a}}$ & 2.000 & 282.000 & .000 & .487 & 267.398 & 1.000 \\
\hline $\begin{array}{c}\text { a. Computed using alpha } \\
=.05\end{array}$ & & & & & & & \\
\hline $\begin{array}{l}\text { b. Design: Intercept + customer } \\
\text { satisfaction }\end{array}$ & & & & & & & \\
\hline
\end{tabular}

Table 8. Tests of between-subjects effects

\begin{tabular}{|c|c|c|c|c|c|c|c|c|c|}
\hline Source & $\begin{array}{l}\text { Dependent } \\
\text { Variable }\end{array}$ & $\begin{array}{l}\text { Type III } \\
\text { Sum of } \\
\text { Squares }\end{array}$ & df & $\begin{array}{c}\text { Mean } \\
\text { Square }\end{array}$ & $\mathbf{F}$ & Sig. & $\begin{array}{l}\text { Partial } \\
\text { Eta } \\
\text { Squared }\end{array}$ & $\begin{array}{l}\text { Noncent. } \\
\text { Parameter }\end{array}$ & $\begin{array}{l}\text { Observed } \\
\text { Power }^{\text {b }}\end{array}$ \\
\hline \multirow{2}{*}{$\begin{array}{l}\text { Corrected } \\
\text { Model }\end{array}$} & loyalty & $70.997^{\mathrm{a}}$ & 1 & 70.997 & 268.094 & .000 & .486 & 268.094 & 1.000 \\
\hline & $\begin{array}{c}\text { Complaining } \\
\text { behavior }\end{array}$ & $2.475^{\mathrm{c}}$ & 1 & 2.475 & 4.888 & .028 & .017 & 4.888 & .596 \\
\hline \multirow[t]{2}{*}{ Intercept } & loyalty & 37.672 & 1 & 37.672 & 142.253 & .000 & .335 & 142.253 & 1.000 \\
\hline & $\begin{array}{c}\text { Complaining } \\
\text { behavior }\end{array}$ & 347.598 & 1 & 347.598 & 686.569 & .000 & .708 & 686.569 & 1.000 \\
\hline \multirow{2}{*}{$\begin{array}{l}\text { Customer } \\
\text { satisfaction }\end{array}$} & loyalty & 70.997 & 1 & 70.997 & 268.094 & .000 & .486 & 268.094 & 1.000 \\
\hline & $\begin{array}{c}\text { Complaining } \\
\text { behavior }\end{array}$ & 2.475 & 1 & 2.475 & 4.888 & .028 & .017 & 4.888 & .596 \\
\hline \multirow[t]{2}{*}{ Error } & loyalty & 74.945 & 283 & .265 & & & & & \\
\hline & $\begin{array}{c}\text { Complaining } \\
\text { behavior }\end{array}$ & 143.278 & 283 & .506 & & & & & \\
\hline \multirow[t]{2}{*}{ Total } & loyalty & 2293.775 & 285 & & & & & & \\
\hline & $\begin{array}{c}\text { Complaining } \\
\text { behavior }\end{array}$ & 3294.667 & 285 & & & & & & \\
\hline \multirow{2}{*}{$\begin{array}{l}\text { Corrected } \\
\text { Total }\end{array}$} & loyalty & 145.942 & 284 & & & & & & \\
\hline & $\begin{array}{c}\text { Complaining } \\
\text { behavior }\end{array}$ & 145.753 & 284 & & & & & & \\
\hline \multicolumn{3}{|c|}{$\begin{array}{l}\text { a. R Squared }=.486 \text { (Adjusted R Squared } \\
=.485)\end{array}$} & & & & & & & \\
\hline \multicolumn{3}{|c|}{ b. Computed using alpha $=.05$} & & & & & & & \\
\hline $\begin{array}{l}\text { c. R Squarec } \\
=.014)\end{array}$ & .017 (Adjusted & squared & & & & & & & \\
\hline
\end{tabular}




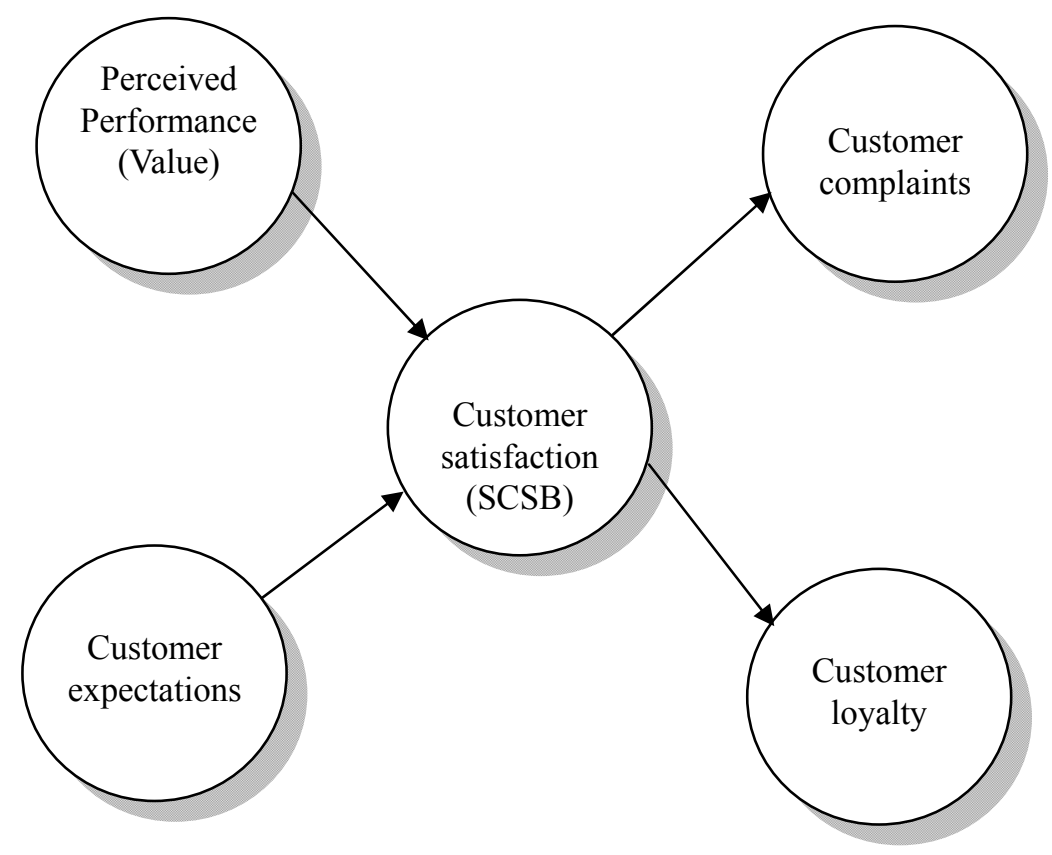

Figure 1. The original SCSB (Swedish Customer Satisfaction Barometer)

Model (Johnson et al., 2001)

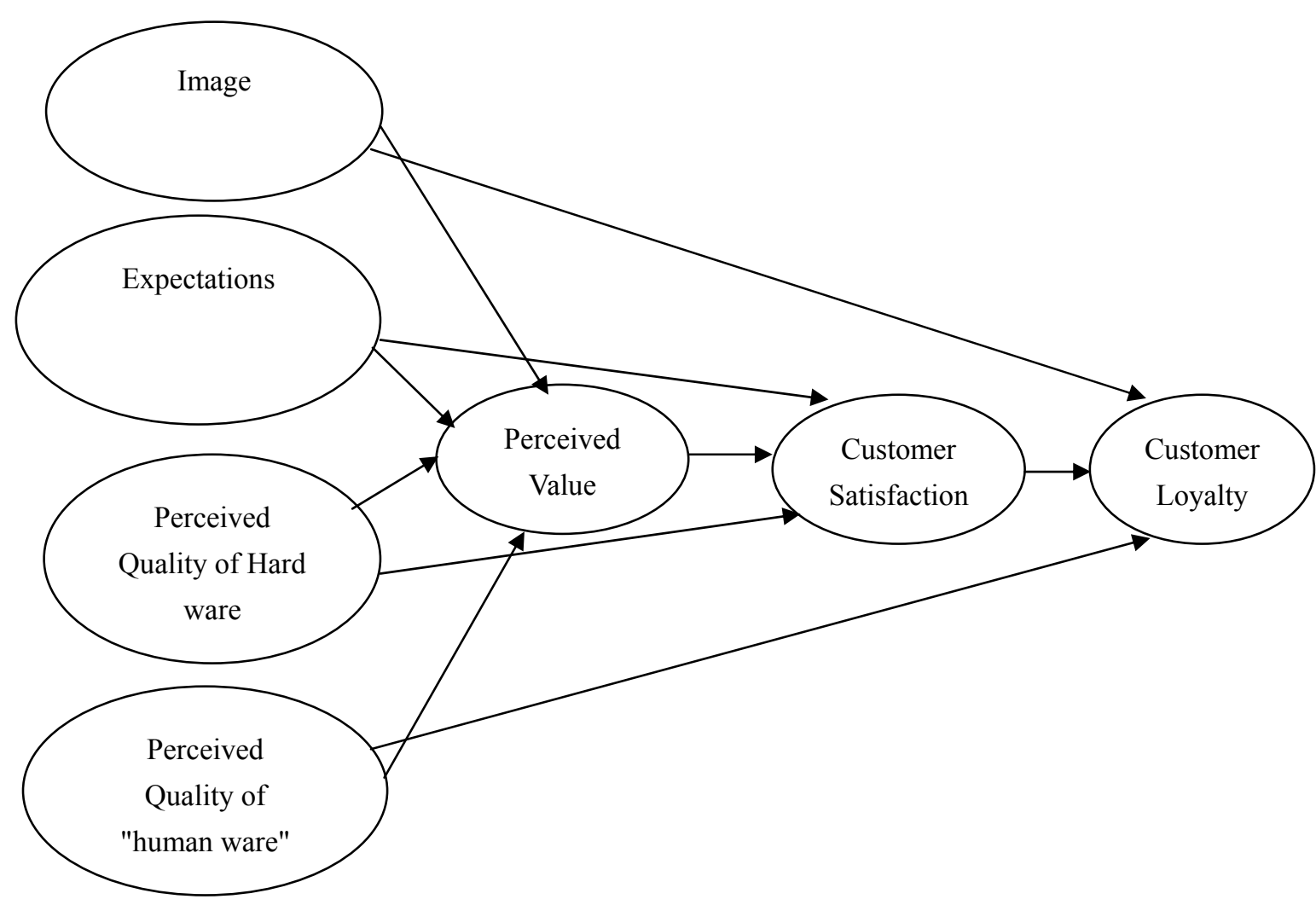

Figure 2. The ACSI (American Customer Satisfaction Index) model (Johnson et al., 2001) 


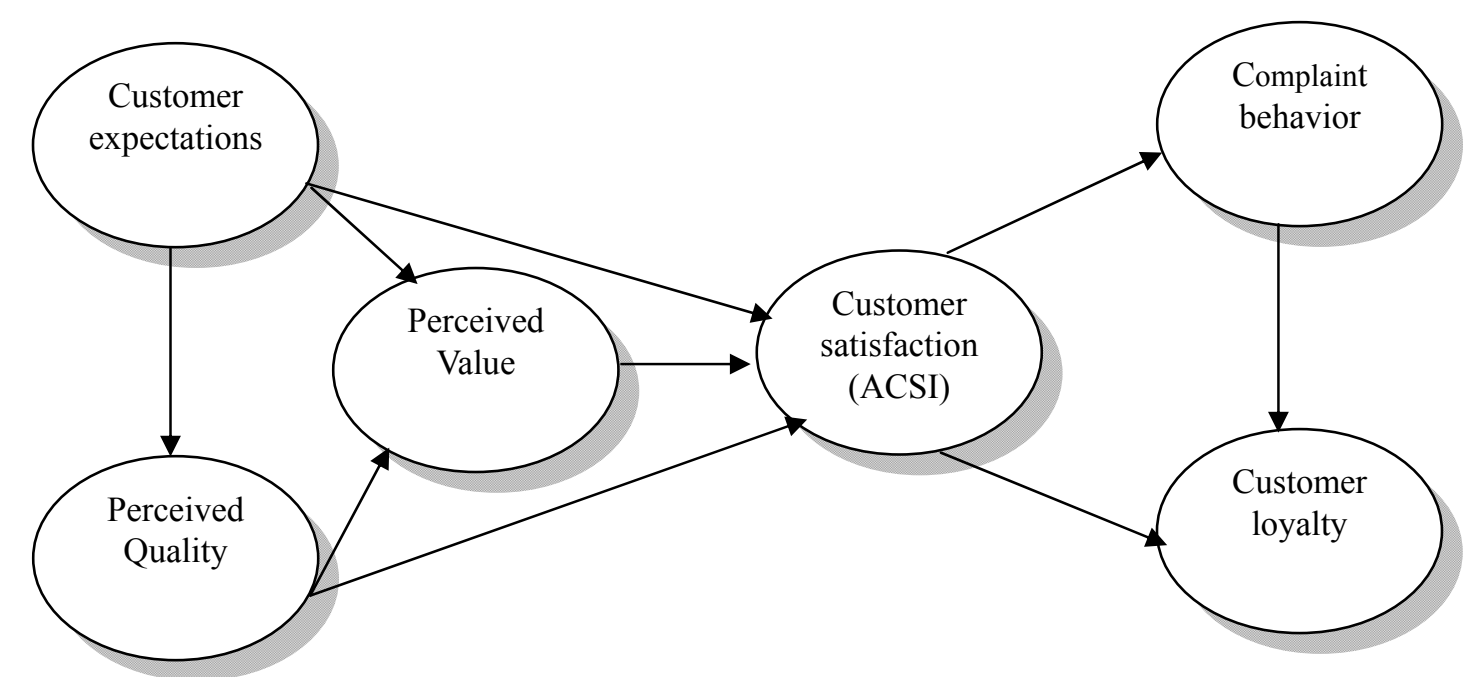

Figure 3. The basic ECSI model (Juhl et al, 2002)

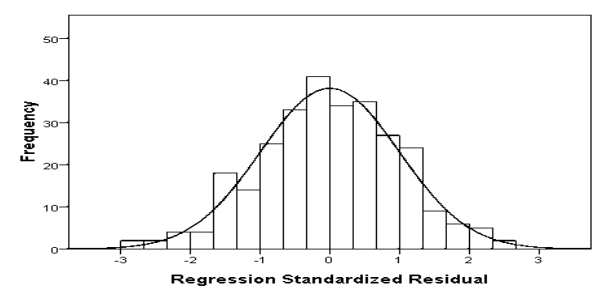

Figure 4. Normality histogram

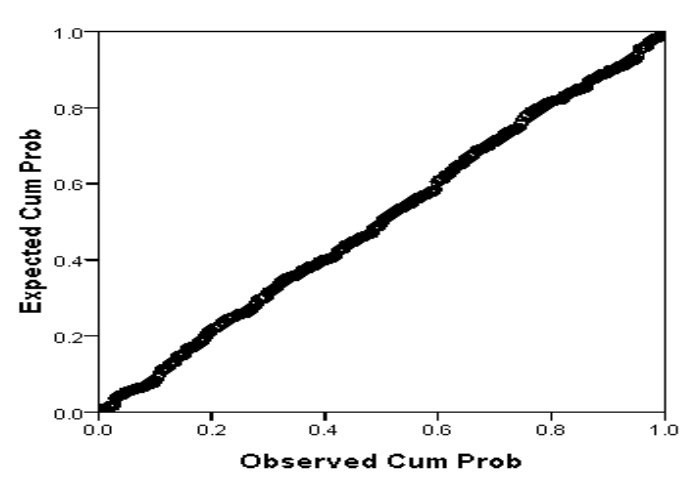

Figure 5. Normality line 


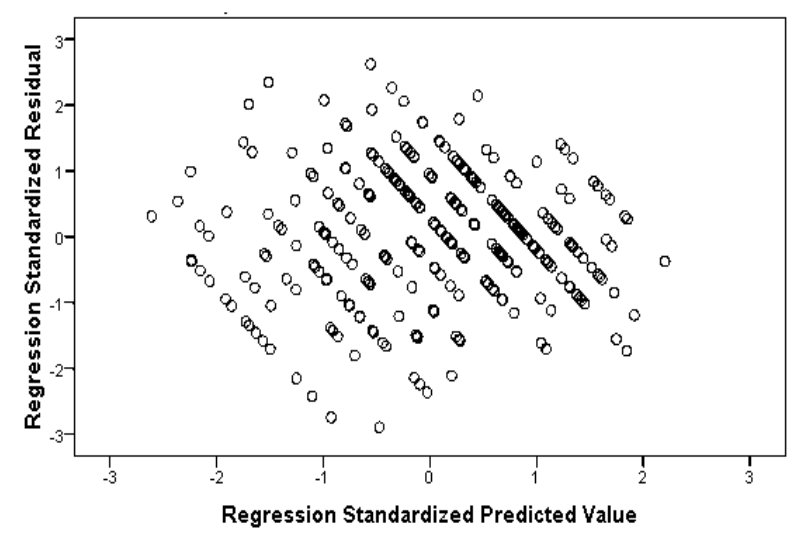

Figure 6. Linearity and equality of variances assessment

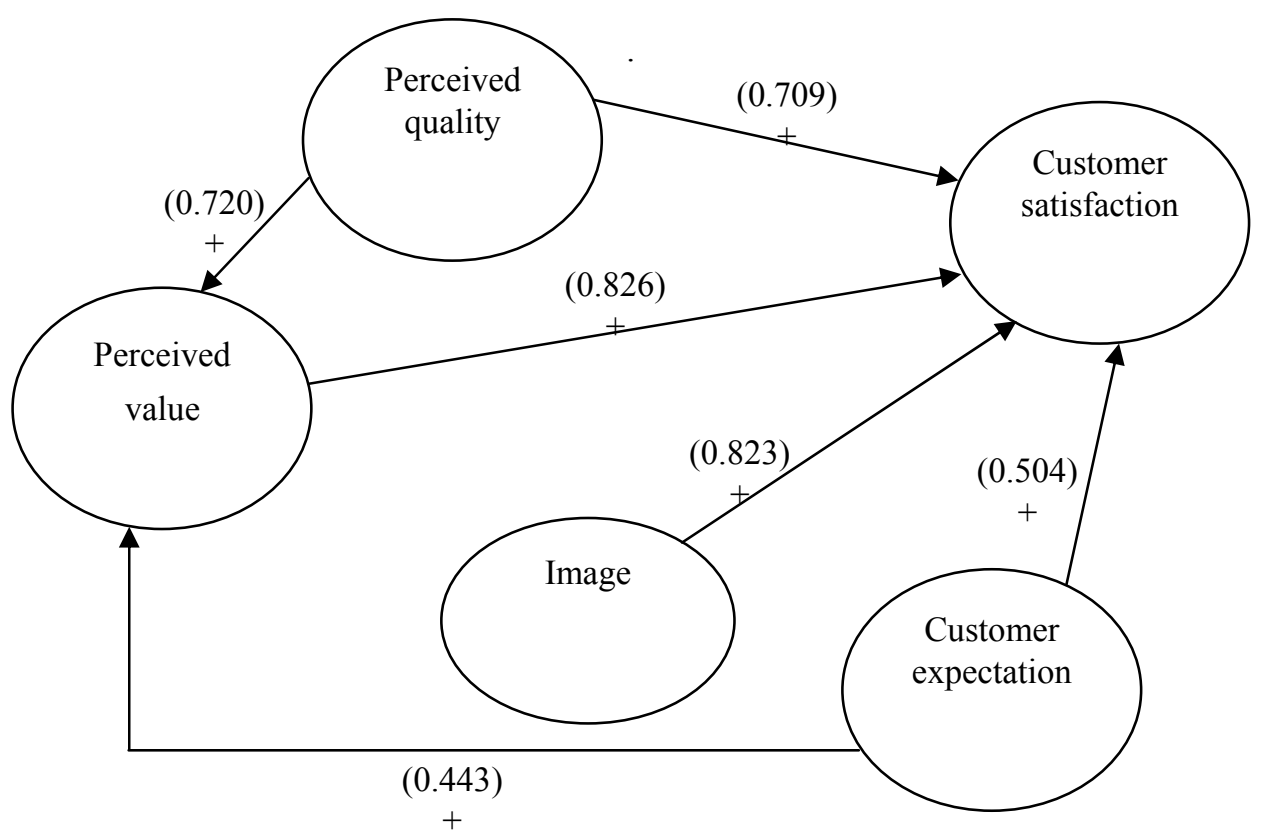

Figure 7. Model suggesting the relationship between customer expectation, perceived quality, perceived value, and image and customer satisfaction 


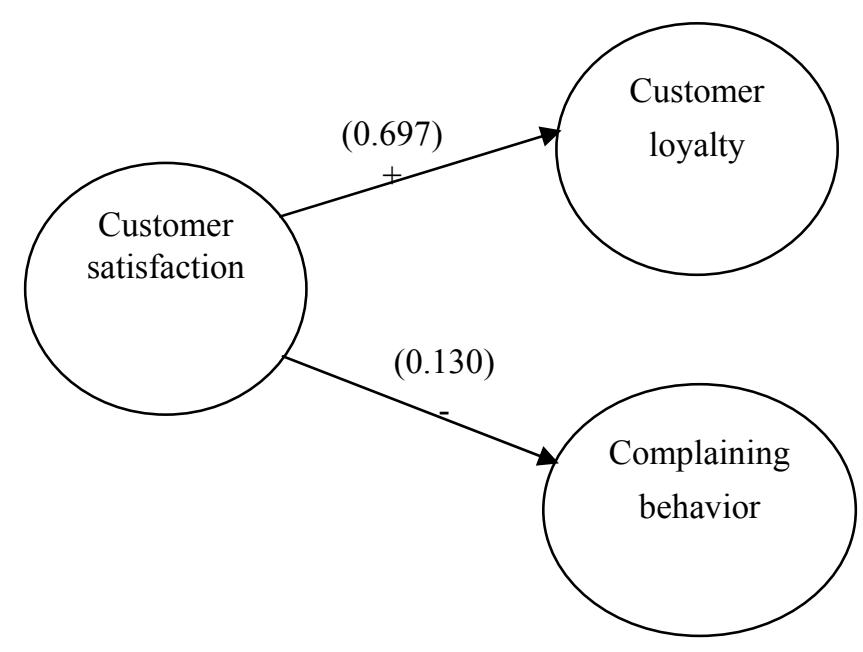

Figure 8. Model suggesting the relationship between customer satisfaction, complaining behavior and customer loyalty

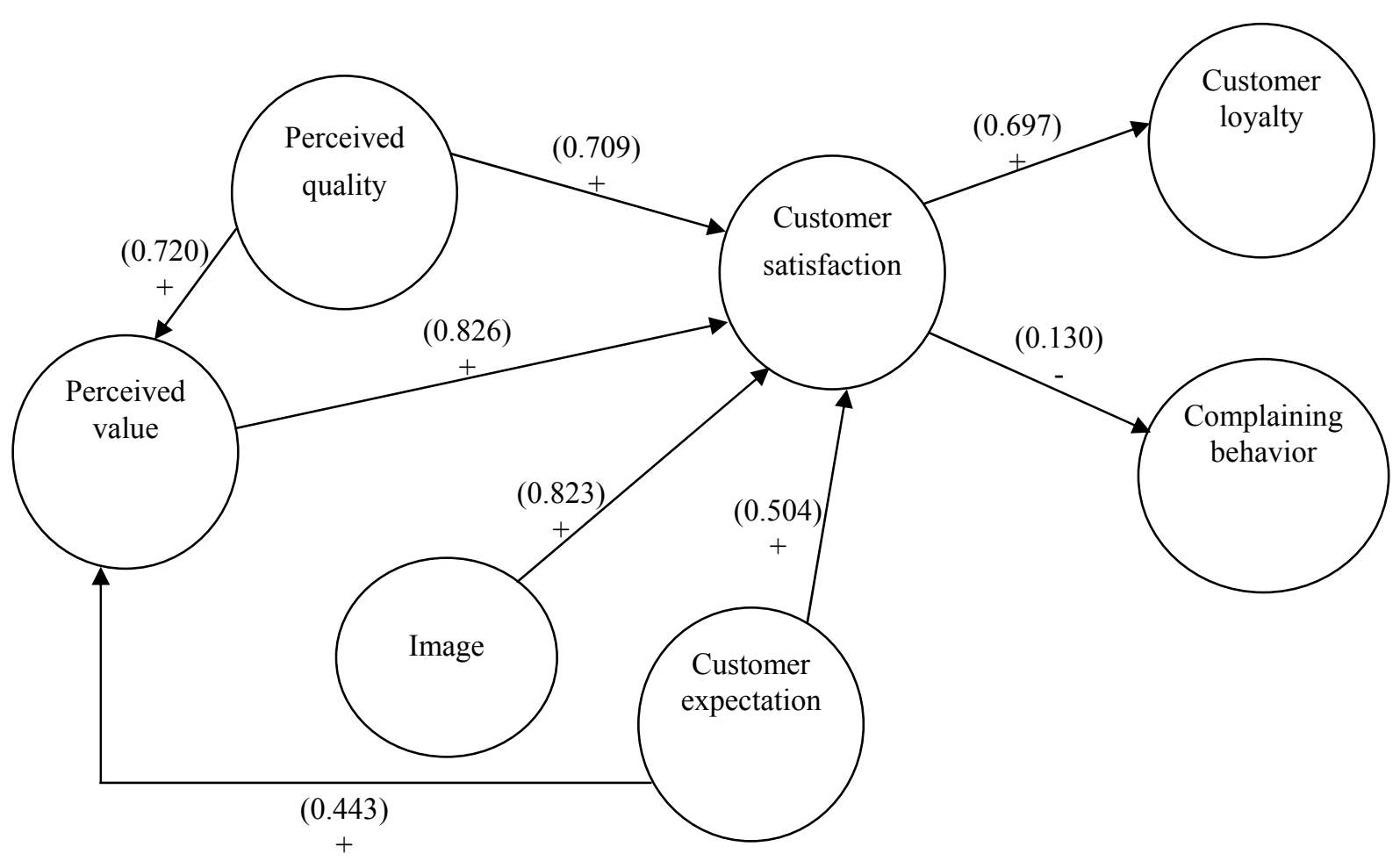

Figure 9. Kish customer satisfaction model in hotel industry (KCSM) 